\title{
Viral diversity and prevalence gradients in North American Pacific Coast grasslands
}

\author{
Eric W. Seabloom, ${ }^{1,4}$ Elizabeth T. Borer,${ }^{1}$ Charles E. Mitchell,${ }^{2}$ and Alison G. Power ${ }^{3}$ \\ ${ }^{1}$ Oregon State University, Department of Zoology, 3029 Cordley Hall, Corvallis Oregon 97330 USA \\ ${ }^{2}$ Department of Biology, University of North Carolina, Chapel Hill, North Carolina 27599 USA \\ ${ }^{3}$ Department of Ecology and Evolutionary Biology, Cornell University, Ithaca, New York 14853 USA
}

\begin{abstract}
Host-pathogen interactions may be governed by the number of pathogens coexisting within an individual host (i.e., coinfection) and among different hosts, although most sampling in natural systems focuses on the prevalence of single pathogens and/or single hosts. We measured the prevalence of four barley and cereal yellow dwarf viruses (B/CYDVs) in three grass species at 26 natural grasslands along a $2000-\mathrm{km}$ latitudinal gradient in the western United States and Canada. B/CYDVs are aphid-vectored RNA viruses that cause one of the most prevalent of all plant diseases worldwide. Pathogen prevalence and coinfection were uncorrelated, suggesting that different forces likely drive them. Coinfection, the number of viruses in a single infected host ( $\alpha$ diversity), did not differ among host species but increased roughly twofold across our latitudinal transect. This increase in coinfection corresponded with a decline in among-host pathogen turnover ( $\beta$ diversity), suggesting that B/CYDVs in northern populations experience less transmission limitation than in southern populations. In contrast to pathogen diversity, pathogen prevalence was a function of host identity as well as biotic and abiotic environmental conditions. Prevalence declined with precipitation and increased with soil nitrate concentration, an important limiting nutrient for hosts and vectors of B/CYDVs. This work demonstrates the need for further studies of processes governing coinfection, and the utility of applying theory developed to explain diversity in communities of free-living organisms to pathogen systems.
\end{abstract}

Key words: alpha diversity; aphid-vectored RNA virus; barley and cereal yellow dwarf virus ( $B / C Y D V)$; beta diversity; community ecology; disease ecology; Pacific coast, North America, grasslands.

\section{INTRODUCTION}

Host-pathogen interactions in natural systems take place within the context of complex food webs comprised of interacting hosts, pathogens, consumers, and vectors (Packer et al. 2003, Lello et al. 2004, Collinge and Ray 2006a, Cumming and Guegan 2006, Keesing et al. 2006, Borer et al. 2009b, Seabloom et al. 2009). Furthermore, the abiotic environment may ultimately mediate these community interactions (Guernier et al. 2004, Pope et al. 2005, Collinge and Ray 2006a, Cumming and Guegan 2006, Minakawa et al. 2006). For example, increased nutrient availability can increase vector populations of important human pathogens (such as malaria: Pope et al. 2005) and plant pathogens (such as barley and cereal yellow dwarf viruses; Borer et al. 2009a).

Despite the clear importance of community and environmental context, the community ecology of disease is a nascent field relative to the vast and welldeveloped literature on single host-pathogen interactions (Anderson and May 1986, Begon et al. 1992,

Manuscript received 24 November 2008; revised 24 April 2009; accepted 1 May 2009; final version received 1 June 2009. Corresponding Editor S. K. Collinge.

${ }^{4}$ E-mail: seabloom@science.oregonstate.edu
Norman et al. 1994, Woolhouse et al. 2001, Holt et al. 2003, Dobson 2004). As a result of this focus on the dynamics of single pathogens, we have a greater understanding of the processes regulating pathogen prevalence than those that govern pathogen diversity. However, most hosts are coinfected by multiple pathogens, and coinfection (i.e., the number of pathogens coexisting within a host individual) can dramatically change pathogen virulence (i.e., the severity of the symptoms arising from infection) and transmission (Lello et al. 2004, Pedersen and Fenton 2007, Jolles et al. 2008, Seabloom et al. 2009).

Coinfection can increase host mortality in both plant and animal hosts (Lal et al. 1994, Miller and Rasochova 1997, Kamal et al. 2001a, b, Hood 2003, Tirado and Yoon 2003). For example, disease symptoms are much more severe for humans coinfected with malaria and human immunodeficiency virus, or the hepatitis $\mathrm{C}$ virus and the trematode Schistosoma mansoni (Lal et al. 1994, Kamal et al. 2001a, b, Tirado and Yoon 2003). Coinfection can alter transmission rates, reducing transmission by reducing vector efficiency, viral titers, or sporulation rates (Gildow and Rochow 1980, Gray et al. 1991, Wen et al. 1991, Power 1996, Al-Naimi et al. 2005). Conversely, coinfection can increase transmission by raising pathogen reproduction (as in antibody- 
dependent enhancement), lowering the ability of hosts to resist subsequent infections (e.g., immunodeficiency syndromes such as AIDS), or increasing the suite of efficient vectors (Rochow 1970b, Creamer and Falk 1990, Montefiori et al. 1996, Bentwich et al. 1999, Yazdanbakhsh et al. 2002, Coico et al. 2003, Tirado and Yoon 2003, Koskella et al. 2006, Jolles et al. 2008).

Given that coinfection can alter pathogen transmission rates and virulence, there is a clear need for studies that simultaneously investigate the regulators of both pathogen prevalence and coinfection. Coinfection can be regulated by factors operating at a wide range of spatial scales ranging from interactions taking place within single individuals, such as coinfection-induced changes in transmission and host mortality, to large-scale gradients in the climate, vector community, or host community (Dempster and Holmes 1995, Power 1996, Cumming and Guegan 2006, Borer et al. 2009b, Seabloom et al. 2009).

While similarly complex processes govern the diversity of free-living organisms, community ecology theory has been successful at describing emergent diversity patterns with fairly simple models. For example a basic organizing principle of community ecology predicts that local-scale diversity ( $\alpha$ diversity) will reflect both the size of the species pool in the larger landscape ( $\gamma$ diversity) and the turnover in community composition among different sites ( $\beta$ diversity; Whittaker 1960, Caley and Schluter 1997, Whittaker et al. 2001). Simple mathematical relationships have been described for these community characteristics; the relationship among these diversity scales can be expressed as $\alpha=\gamma / \beta$ and $\beta=\gamma / \alpha$ (Whittaker 1960, Harrison et al. 1992) or as $\alpha=\gamma-\beta$ and $\beta=\gamma-\alpha$ (Whittaker et al. 2001, Dove and Cribb 2006). Recently, it has been suggested that the relationship between $\alpha, \beta$, and $\gamma$ diversity, that is well-studied in free-living organisms, can clarify the mechanisms governing coinfection by pathogens and parasites; however, empirical tests are lacking (Dove and Cribb 2006).

Dove and Cribb (2006) observe that coinfection (infracommunity diversity or within-host pathogen diversity) and $\alpha$ diversity are analogous, as are the total number of pathogens among coexisting hosts (component-community diversity) and $\gamma$ diversity. In parasite communities with low $\beta$ diversity (termed niche-assembled, interactive, or $\alpha$-dominated communities; Holmes and Price 1986, Dove and Cribb 2006, Chase 2007), each host contains a similar and nearly complete set of the total pathogen pool. In these low $\beta$ diversity communities, each pathogen is found in most hosts, implying that either pathogen transmission rates are high, or pathogen loss rates to recovery and mortality are low. As a result, each host has a predictable suite of pathogens and the within-host pathogen community is primarily governed by processes that determine pathogen diversity at larger spatial scales (i.e., $\gamma$ diversity), such as a gradient in the physical environment or vector diversity (Guernier et al.
2004, Cumming and Guegan 2006, Dove and Cribb 2006, Chase 2007). In contrast, in communities with high $\beta$ diversity (termed neutral, dispersal-assembled, isolationist, or $\beta$-dominated communities; Holmes and Price 1986, Dove and Cribb 2006, Chase 2007), individual hosts contain a small, random subset of the total pathogen species pool at any single site. In these communities with high $\beta$ diversity, each pathogen is found in only a small proportion of hosts, implying that either transmission rates are low or pathogen loss rates are high. Furthermore, within-host pathogen communities in high $\beta$ diversity systems are largely driven by stochastic infection events, and the pathogen community within any given host is largely unpredictable (Dove and Cribb 2006).

As with coinfection, pathogen prevalence may be governed by processes acting at a broad range of spatial scales. At larger scales, spatial or temporal variability in the abiotic environment can directly affect transmission of different pathogens by altering vector reproduction, vector community composition, pathogen reproduction, and pathogen transmission (Gregory 1973, Agrios 1978, Fitt et al. 1989, Madden et al. 1996, Aylor 1999, Cumming and Guegan 2006). For example, rainfall, temperature, and nutrient supplies have been shown to alter the prevalence of a range of diseases (Townsend et al. 2003, Zhou et al. 2004, Pope et al. 2005, Minakawa et al. 2006, Snall et al. 2008, Borer et al. 2009a). Recently, abiotic effects on both vectored and directly transmitted pathogens have received a great deal of attention within the context of human alteration of global climate and nutrient supply rates (Lindsay and Birley 1996, Harvell et al. 1999, Reiter 2001, Harvell et al. 2002, Townsend et al. 2003, Pounds et al. 2006, Dobson 2009).

As with abiotic gradients, large-scale gradients in host community composition can regulate generalist pathogens via a variety of pathways. In particular, hosts in communities dominated by highly competent hosts (i.e., hosts that readily carry and transmit a pathogen) can experience elevated transmission rates, infection risk, and overall pathogen prevalence (Keesing et al. 2006). For vectored pathogens, the composition of host communities can control the encounter rates between vectors and highly competent hosts (e.g., "dilution" or "spillover"; Power and Mitchell 2004, Keesing et al. 2006). Host composition also can control vector abundance when vector population dynamics depend upon host composition (Keesing et al. 2006, Borer et al. 2009a, Dobson 2009).

Coinfection may also arise from host-specific interactions with the pathogen and/or vector. For example, hosts may differ in their innate susceptibility to infection (Macdonald 1957, Service 1976, Ault 1994, Shrestha et al. 2006), desirability or value to vectors (Malmstrom et al. 2005b, Borer et al. 2009a), or their transmission competence and role as a reservoir species for the pathogen (LoGiudice et al. 2003, Power and Mitchell 
2004). Thus, at a single location different host species may exhibit consistent differences in coinfection.

Thus, while it is widely acknowledged that host and pathogen community context mediate the distribution of pathogens among hosts in natural systems, few largescale studies simultaneously investigate the effects of the abiotic and biotic environment on a community of pathogens in multiple hosts. To bridge this gap we surveyed the prevalence and diversity of four barley and cereal yellow dwarf viruses (B/CYDVs) in three host species in 26 natural grasslands along a $2000 \mathrm{~km}$ latitudinal gradient in the western United States and Canada (Fig. 1). We measured infection by four $\mathrm{B} / \mathrm{CYDV}$ pathogens in three hosts from three different tribes in the subfamily Poodieae that differ strongly in their interactions with both pathogens and their aphid vectors: Avena fatua (an exotic annual that is highly valuable to vectors and strongly impacted by the pathogen at the individual level), Bromus hordeaceus (an exotic annual that is highly valuable to vectors and strongly impacted by the pathogen at the individual level), and Elymus glaucus (a native perennial that is of low value to vectors but strongly impacted by the pathogen at the individual level; see Appendix: Table 1; and the Study system section). We also tested site-level abiotic and biotic factors that have been suggested as drivers of pathogen dynamics, including rainfall, soil nitrogen, and host and non-host biomass and abundance.

We use these data to investigate the effects of the abiotic environment, host community composition, and host identity on prevalence and coinfection. We also use the changes in pathogen $\alpha, \beta$, and $\gamma$ diversity to determine the relative importance of niche and dispersal assembly in the pathogen community along this large geographic gradient. Specifically, we address the following four questions. (1) Does host identity alter pathogen prevalence or diversity? (2) Does the abiotic environment (latitude, precipitation, or soil resources) alter pathogen prevalence or diversity? (3) Does the host community (plant standing crop, host richness, and relative abundance of non-hosts, low-quality hosts, and high-quality hosts) alter pathogen prevalence or diversity? (4) Is coinfection regulated by the total pathogen pool at a site (i.e., low $\beta$ diversity or niche-assembled communities) or the turnover in pathogens among coexisting hosts (i.e., high $\beta$ diversity or neutralassembled communities)?

In addition to providing insight into this important suite of grassland pathogens, a further goal of this work is to demonstrate the feasibility of using observational data to investigate the biotic and abiotic drivers of pathogen diversity across spatial scales that extend beyond those that are feasible for experimentation.

\section{Study System}

B/CYDVs are a suite of aphid-vectored RNA viruses in the Luteoviridae known to infect over 150 grass

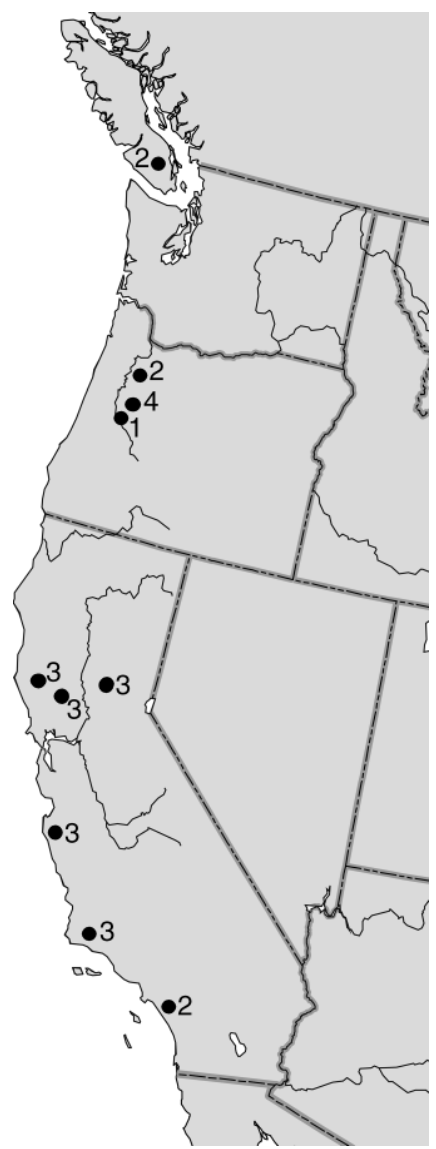

FIG. 1. Study sites (solid circles) for field survey of barley and cereal yellow dwarf viruses $(\mathrm{B} / \mathrm{CYDV})$ prevalence and diversity on the Pacific coast of North America (USA and Canada). Where symbols for multiple populations overlap, numbers indicate the number of populations sampled.

species in over 40 different genera (Irwin and Thresh 1990, D'Arcy 1995). These known hosts are distributed widely throughout the Poaceae and include five of the six subfamilies and 11 of the 25 tribes (Irwin and Thresh 1990, D'Arcy 1995). These phloem-limited pathogens cause one of the most devastating diseases of small grain crops and are some of the most prevalent of all viral pathogens globally (Irwin and Thresh 1990). Recent work suggests that the presence of these viruses was likely a necessary precondition to one of the most widespread and persistent plant invasions worldwide (Malmstrom et al. 2005b, Borer et al. 2007), the conversion of $25 \%$ of the area of California to annual grassland dominated by exotic species from the Mediterranean region (Heady 1977, Seabloom et al. 2003).

Infection by $\mathrm{B} / \mathrm{CYDV}$ leads to increased mortality, stunted growth, and decreased fecundity in crops and grasses (Rochow 1970a, D'Arcy 1995, Malmstrom et al. 2005a). There is no vertical transmission of the viruses; all seedlings of infected parents are initially uninfected (Rochow 1970a). The lack of vertical transmission means that the pathogen cannot persist in a strictly 
annual system with non-overlapping generations (i.e., strong seasonality). In these systems, epidemics are likely to be started by the arrival of viruliferous, migrant aphids from distant areas where they persist year round (Irwin and Thresh 1988, Hewings and Eastman 1995). The presence year round of irrigated cereal crop production can allow local persistence in annual-only systems, and has been associated with increased pathogen prevalence in crops (Hewings and Eastman 1995). These viruses also can persist in the vegetative parts of wild perennial grasses (Borer et al. 2007).

$\mathrm{B} / \mathrm{CYDV}$ s are transmitted by at least 25 different aphid species worldwide (Halbert and Voegtlin 1995). The viruses do not replicate in the aphid vectors and are not transmitted to aphid offspring (Rochow 1970a, Agrios 1978). Aphids can acquire the viruses in as short as 15 minutes, and viruliferous aphids can inoculate a plant in two hours, though efficiency increases with acquisition and inoculation time (Gray et al. 1991, Power et al. 1991).

BYDV and CYDV species belong to distinct genera, and interactions among the different viral species can alter the transmission and virulence of $\mathrm{B} / \mathrm{CYDVs}$ (Miller and Rasochova 1997). For example, cross protection occurs between BYDVs but not between BYDVs and CYDVs (Miller and Rasochova 1997). While congeneric viruses can provide a degree of cross protection, infection by viruses from different genera (e.g., BYDV-PAV and CYDV-RPV) can lead to increased disease severity (Miller and Rasochova 1997). In general, cross protection and synergistic mortality from mixed infection should lead to lower levels of coinfection, although this has not been detected in field populations (Seabloom et al. 2009).

Host species differ strongly in their interactions with these viral pathogens and their vectors (Appendix: Table 1). In the broadest sense, aphid vectors have two to three times higher colonization and fecundity on annual hosts than on perennial hosts, leading to higher observed hostprevalence rates in the field (Malmstrom et al. 2005b, Borer et al. 2007, 2009a). Among annual grasses, $A$. fatua (one of our target hosts) is a particularly competent host for $\mathrm{B} / \mathrm{CYDV}$ pathogens, creating a strong spillover effect on adjacent host species (Power and Mitchell 2004, Malmstrom et al. 2005b). In addition, pathogen prevalence and diversity in annual hosts represent the spread of B/CYDV pathogens within a single season, because all annual seedlings are uninfected at germination (i.e., our target annual hosts, $B$. hordeaceus and A. fatua). In contrast, perennial grass hosts (e.g., our target host, E. glaucus) do not generally lose infections among years but rather tend to accumulate $\mathrm{B} / \mathrm{CYDV}$ pathogens throughout their lifetime, leading to an increase in prevalence over time (Dempster and Holmes 1995, Power and Mitchell 2004, Seabloom et al. 2009).

B/CYDV aphid vector species differ strongly in their efficiency at transmitting different viruses. The most common vectors at our study sites are Rhopalosiphum padi, R. maidis, Sitobion avenae (see Plate 1), Metopolophium dirhodum, and Schizaphis graminum (E. T. Borer, unpublished data). Of these species, $R$. maidis and S. graminum each efficiently transmit only a single viral species (BYDV-RMV and BYDV-SGV, respectively). In contrast, $R$. padi is an efficient vector for both BYDV-PAV and CYDV-RPV. Similarly, S. avenae and $M$. dirhodum efficiently transmit two BYDV species (BYDV-PAV and BYDV-MAV; Power and Gray 1995, Miller and Rasochova 1997, Leclercq-Le Quillec et al. 2000). Previous observations in West Coast grasslands, performed at smaller spatial scales than the current study, suggest that B/CYDV viruses are highly aggregated, and that their covariance structure among sites, years, and within hosts is strongly associated with their vector affinity, such that viral species that share a vector are positively correlated both spatially and temporally (Seabloom et al. 2009).

\section{Methods}

\section{Field survey of pathogen prevalence and host community}

We sampled B/CYDV prevalence in natural grasslands at 11 reserves in California, Oregon, and British Columbia (Fig. 1; Appendix: Table 2). At the larger reserves, we sampled up to three populations separated by at least $500 \mathrm{~m}$ (and usually much more) for a total of 26 sample sites. At each site, we collected at least 20 individuals each of Bromus hordeaceus, Elymus glaucus, and Avena fatua (979 individual hosts assayed). Note that not all hosts were present at all sites. We were not able to collect $A$. fatua at Hopland, Hoskins, and Horserock reserves, and we were not able to collect $B$. hordeaceus at Horserock Reserve; however, all results presented are qualitatively similar if we only examine sites at which we collected multiple host species. Hosts were collected at a similar phenological point at each site, the latest possible date at which we could still collect sufficient green tissue from the annual species. Peak aphid abundance generally occurs much earlier in the season (E. T. Borer, unpublished data), so this late season collection represents a point at which most of the transmission has occurred for the current season.

Host tissue samples were shipped by overnight mail for viral assays. Leaf tissue from each host was tested for infection by BYDV-PAV, BYDV-MAV, BYDV-SGV, and CYDV-RPV using enzyme-linked immunosorbent assay (ELISA; Rochow 1986) using antibodies from Agdia, Elkhart, Indiana, USA. To be conservative, in uncommon cases where putative infections by two serologically related viruses were associated nearly $1: 1$ within individuals of a host species at a site, we regarded the putative infections of the virus that elicited the weaker assay response (relative to standard controls on each microplate) as cross reactions to the other virus, rather than as coinfections. This left our estimate of prevalence unchanged, but somewhat reduced our estimate of coinfection. 
At each site, we quantified plant biomass by clipping, drying to constant mass at $60^{\circ} \mathrm{C}$, and weighing to the nearest $0.01 \mathrm{~g}$ all aboveground biomass from two $0.1 \mathrm{~m}$ $\times 1 \mathrm{~m}$ quadrats. We estimated the area covered by each plant species present in two $0.5 \mathrm{~m} \times 1 \mathrm{~m}$ quadrats. Cover was estimated independently for each species, so total cover can sum to more than $100 \%$ in communities with multilayered canopies. We collected and air-dried three $2.5 \mathrm{~cm} \times 10 \mathrm{~cm}$ deep soil cores that were analyzed for total phosphorous, nitrate, potassium, organic matter, sand, silt, clay, and $\mathrm{pH}$ by A \& L Western Agricultural Laboratories (Modesto, California, USA).

\section{Statistical analyses}

All statistical analyses were conducted using $\mathrm{R}$ version 2.5.1 (R Development Core Team 2007). Prevalence data were analyzed with logistic regression, and diversity measures (viral richness within hosts or sites) were analyzed using Poisson regression. In both cases, we used a quasi-likelihood approach (quasibinomial and quasipoisson distributions in the glm function), because the data dispersion did not match the distributional assumptions of the binomial or Poisson distributions (McCullagh and Nelder 1989, Venables and Ripley 2003). In all cases, we tested for host differences and host $X$ environment interactions by including host identity in the regression models. As there were few strong host $X$ environment interactions, we then used a simpler regression model based on mean prevalence and diversity averaged across all hosts.

We tested whether viruses carried by the same vector were more highly correlated than expected at random using Mantel tests. Mantel tests are permutation tests that can be used to test whether multivariate distances in a distance matrix are greater among categories in a design matrix than those within categories, a conceptually similar analysis to a multivariate, nonparametric ANOVA (Mantel 1967, Manly 1986, Sokal and Rohlf 1995). In our analyses, the design matrix was constructed by assigning a value of one to elements representing viral species pairs that shared a vector and a zero to elements representing viral species pairs that did not share a vector (Sokal and Rohlf 1995, Seabloom et al. 2009). Significantly large positive values of the test statistic $Z$ indicate that the viral community is more similar within than among vector affinity categories. The observed value of $Z$ was compared to the distribution of values obtained in 1000 random permutations of the viral species correlation matrix. Mantel tests were performed using the mantel.test function in the ape $\mathrm{R}$ library.

\section{Results}

Our sample sites spanned a wide range of environmental conditions. Our collection locations spanned 15 degrees of latitude, from $33.8^{\circ}$ to $48.8^{\circ} \mathrm{N}$. Among these sites, rainfall during the 2006 growing season (August 2005 to July 2006) ranged from $224 \mathrm{~mm}$ to $1504 \mathrm{~mm}$, and total standing crop ranged from 22 to $898 \mathrm{~g} / \mathrm{m}^{2}$. Soil chemistry was correspondingly variable among sites in nitrogen (2-10 ppm nitrate), phosphorus (4-47 ppm), potassium (55-485 ppm), pH (5-7.7), organic matter (2.1-6.9\%), sand (34-74\%), silt (12-48\%), and clay (6$26 \%$ ). Of these factors, only latitude, rainfall, and nitrate were significant factors in any model of prevalence or coinfection (Appendix: Tables 3, 4, and 5). We were missing soil nitrate data from three sites, so we conducted all regression analyses on the full data set without soil nitrate, and also on the more restricted data set that included the soil nitrate data. There was a strong positive relationship between prevalence and soil nitrate, so we separately present regression analyses on the full set of data without soil nitrate (Appendix: Tables 3, 4), and the univariate tests of soil nitrate effects on prevalence and coinfection (Appendix: Table 5).

The composition of the host community also varied widely across our 26 sampled populations. Non-host cover (i.e., cover summed across all forb species) ranged from $12 \%$ to $153 \%$ cover, low-quality host cover (i.e., cover summed across all perennial grass species) ranged from $0 \%$ to $68 \%$ cover, high-quality host cover (i.e., cover summed across all annual grass species) ranged from $0 \%$ to $130 \%$, the percent of the community composed of hosts (total grass cover/total cover) ranged from $7-85 \%$, and host (grass) species richness ranged from one to seven species per $0.5 \mathrm{~m}^{2}$. Note that cover of each species was estimated independently, so summed cover values exceeding $100 \%$ indicate a multilayer canopy. The only host-community relationship in our regression models was a positive relationship between the cover of perennial grasses and prevalence in one host species (B. hordeaceus; Appendix: Table 3). We were missing plant-community biomass from six sites, so we repeated all regression analyses on the more restricted data set that included biomass. Community biomass was not significant in any models.

Prevalence of virus infection across all sampled hosts was $20.7 \%$, and prevalence within sampled populations ranged from $0 \%$ to $70 \%$. Single virus prevalence rates were as follows: $13.1 \%$ BYDV-PAV, $11.5 \%$ BYDVMAV, $8.3 \%$ CYDV-RPV, and $3.6 \%$ BYDV-SGV. The mean number of viruses in infected hosts was 1.68 . Prevalence and coinfection (the average number of strains in infected hosts) were uncorrelated among sites $(r=0.06)$. With 26 samples, the $95 \%$ confidence interval for $r$ is $-0.35<r<0.45$ and accordingly $r^{2}$ could reach 0.12 or 0.20 given the variability in the estimate for $r$ (i.e., the sign of $r$ ). Thus the vast majority $(>88 \%)$ of the variability in coinfection remains unaccounted for by site-scale prevalence, suggesting that the primary drivers of prevalence and coinfection differ.

We tested whether the observed coinfection values were higher than expected by comparing them to the distribution of coinfection values calculated from 1000 random permutations of the individual viral species prevalence data. In our sample, coinfection was much 

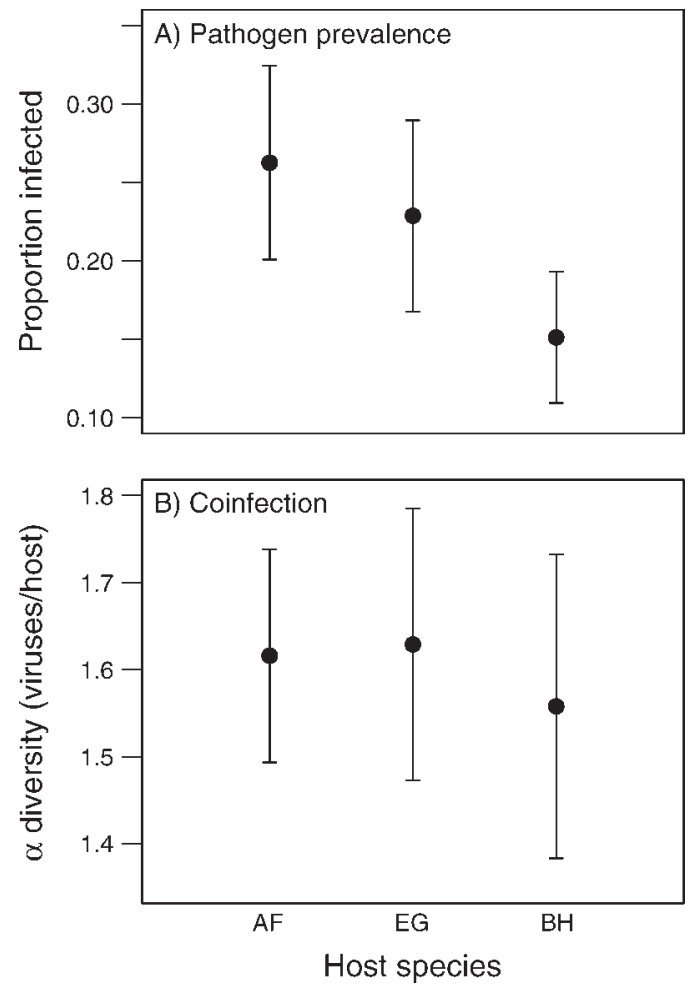

FIG. 2. (A) B/CYDV (barley and cereal yellow dwarf virus) prevalence and (B) viral $\alpha$ diversity or viruses per infected host for three host species: Avena fatua (AF), Elymus glaucus (EG), and Bromus hordeaceus (BH). A. fatua and B. hordeaceus are annual grasses; E. glaucus is a perennial bunchgrass.

higher than expected at random; the observed data had fewer singly infected and more multiply infected hosts than expected if the occurrences of the viruses were distributed randomly with respect to one another $(P<$ 0.001). Of the infected hosts, $39 \%$ were infected with at least two viruses and $14 \%$ carried three or more viruses. By comparison, only $9 \%$ (range of $7-12 \%$ ) of the hosts were expected to carry two viral species and $<1 \%$ were expected to carry three species (range of $0-2 \%$ ) in the permuted data.

Using a Mantel test, we found that viral species sharing a vector were significantly positively correlated $(P<0.001)$. For example, BYDV-PAV and CYDVRPV, both carried by $R$. padi, had a correlation coefficient of $0.50(P<0.0001)$. Similarly, BYDVPAV and BYDV-MAV, both vectored by $S$. avenae and M. dirhodum, had a correlation coefficient of $0.50(P<$ 0.0001). In contrast, BYDV-SGV, the only B/CYDV viral species efficiently transmitted by $S$. graminum, had correlations very close to zero with all other viruses $(-0.04<r<-0.02)$. While BYDV-MAV and CYDVRPV do not share a known vector, they were positively correlated $(r=0.40, P<0.001)$, perhaps due to an indirect positive association with BYDV-PAV (BYDVPAV and CYDV-RPV share a vector as do BYDV-PAV and BYDV-MAV).

\section{Drivers of prevalence among sites}

Pathogen prevalence differed among hosts, with $A$. fatua, an annual grass of high vector quality, and $E$. glaucus, a perennial bunchgrass of low vector quality, having higher prevalence than $B$. hordeaceus, an annual host of high vector quality (Fig. 2A). Prevalence declined strongly with precipitation and increased with soil nitrate (Fig. 3; Appendix: Tables 3, 4, and 5). The only significant interaction between host identity and any biotic and abiotic factors was with the cover of perennial grass (Appendix: Table 3). Pathogen prevalence increased in B. hordeaceus with increasing cover of perennial grasses, but was unchanged in A. fatua and $E$. glaucus (Appendix: Table 3).

\section{Drivers of coinfection among sites}

In contrast to site-level prevalence, coinfection $(\alpha$ diversity) did not differ among host species (Fig. 2B) and was correlated solely with latitude (Appendix: Table 3; Fig. 3). Coinfection increased from close to 1.0 at our southern sites to 2.5 at our northernmost sites (Fig. 3). This increase was not associated with any systematic change in the site-level pathogen diversity ( $\gamma$ diversity), which was virtually invariant over each gradient (Appendix: Table 3; Fig. 3). There was a strong decline in among-host viral diversity $(\beta=\gamma / \alpha)$ with latitude, as expected, given the lack of variability in site-level pathogen diversity (Appendix: Table 3; Fig. 3). At our northern sites, $\beta$ diversity was close to 1.0 , because all infected hosts carried all available viral species $(\gamma \approx \alpha)$. In contrast, at our southern sites, each host carried less than half the viral species found at the site $(\gamma \approx 2.5 \alpha$; Fig. 3). We note that we find the same pattern of decreasing $\beta$ diversity with latitude when we use the alternate formulation for $\beta$ diversity $(\beta=\gamma-\alpha)$, although the absolute values differ.

\section{DisCusSION}

Spatial patterns of pathogen prevalence and diversity arise within the context of the abiotic environment and biotic pathogen, vector, and host communities; however, the importance of these factors is rarely assessed simultaneously. Here we tested the effects of host identity, abiotic environment (e.g., latitude, precipitation, or soil resources), and the host community (plant standing crop, host richness, and relative abundance of non-hosts, low-quality hosts, and high-quality hosts) on pathogen prevalence and diversity (see questions 1-3 in the Introduction). In addition, we tested whether changes in pathogen coinfection ( $\alpha$ diversity) were primarily regulated by the total pathogen pool at a site (i.e., low $\beta$ diversity or niche-assembled communities) or the turnover in pathogens among coexisting hosts (i.e., high $\beta$ diversity or neutral-assembled communities; see question 4 in the Introduction).

We found that site-level pathogen prevalence and pathogen diversity within infected hosts were uncorre- 

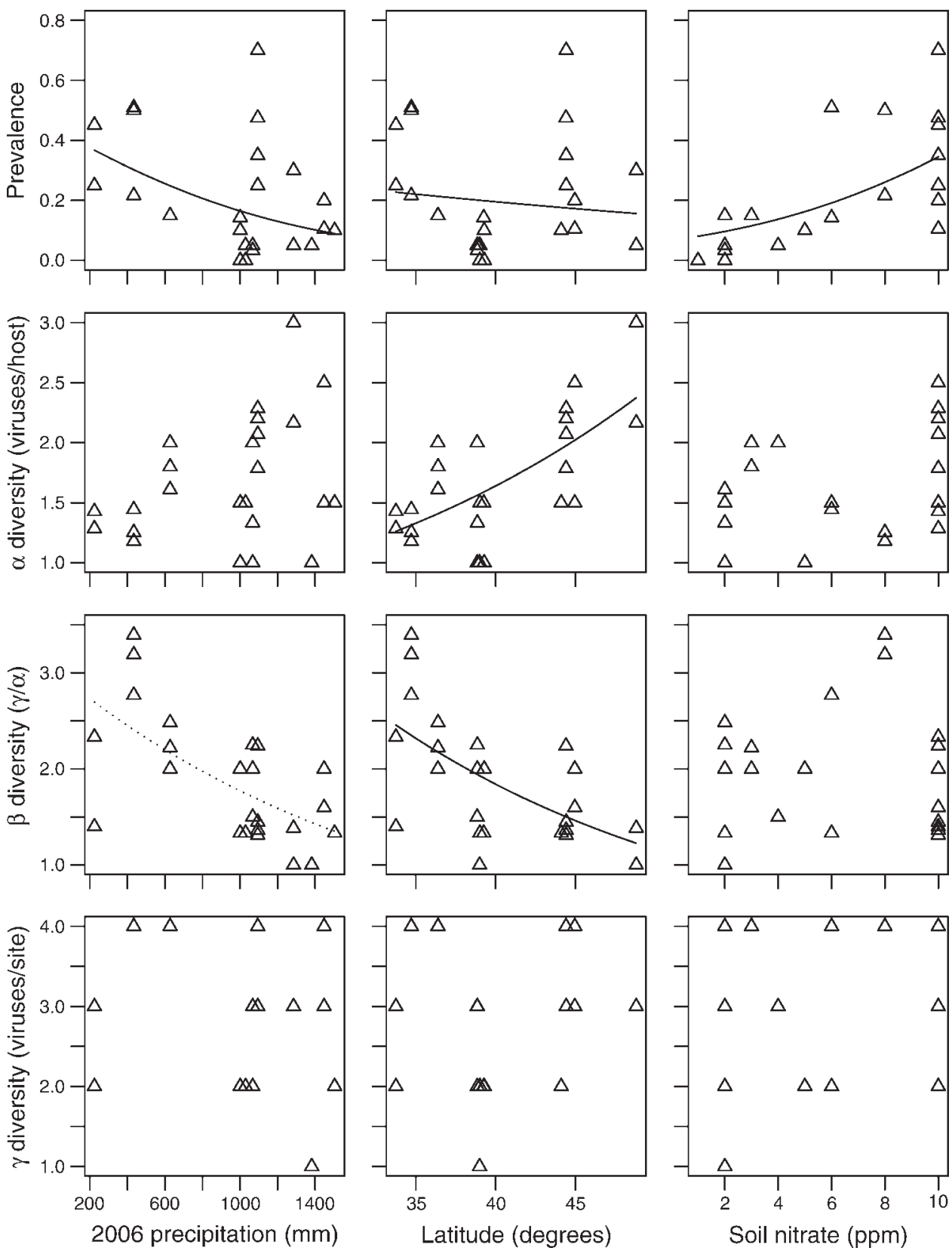

FIG. 3. Determinants of viral prevalence and viral species diversity $(\alpha, \beta$, and $\gamma)$ averaged across three grass hosts $(A$. fatua, $B$. hordeaceus, and E. glaucus) in grasslands on the West Coast of North America. Regression lines are univariate regressions and so differ from the slopes presented in the multiple regression models in the Appendix: Tables A3, A4, and A5. The dotted line indicates a regression that is significant in univariate regression but not in multiple regression models.

lated, suggesting that these patterns were generated by distinct processes. Site-level pathogen prevalence of this suite of vectored, generalist pathogens varied with host identity, while coinfection was similar among host species (question 1). Prevalence and coinfection were both correlated with gradients in the abiotic environment, although the driving factors differed (question 2). Infection prevalence decreased with precipitation and increased with soil nitrate. In contrast, coinfection in all host species increased with latitude but was independent of precipitation and nitrate. Recent theoretical work examining the processes relating prevalence and coinfection suggests that prevalence and coinfection differ in their response across a wide range of interactions among pathogens sharing a host (e.g., cross protection to synergistic mortality; Seabloom et al. 2009). Thus, theory supports the lack of relationship between prevalence and coinfection found here. 


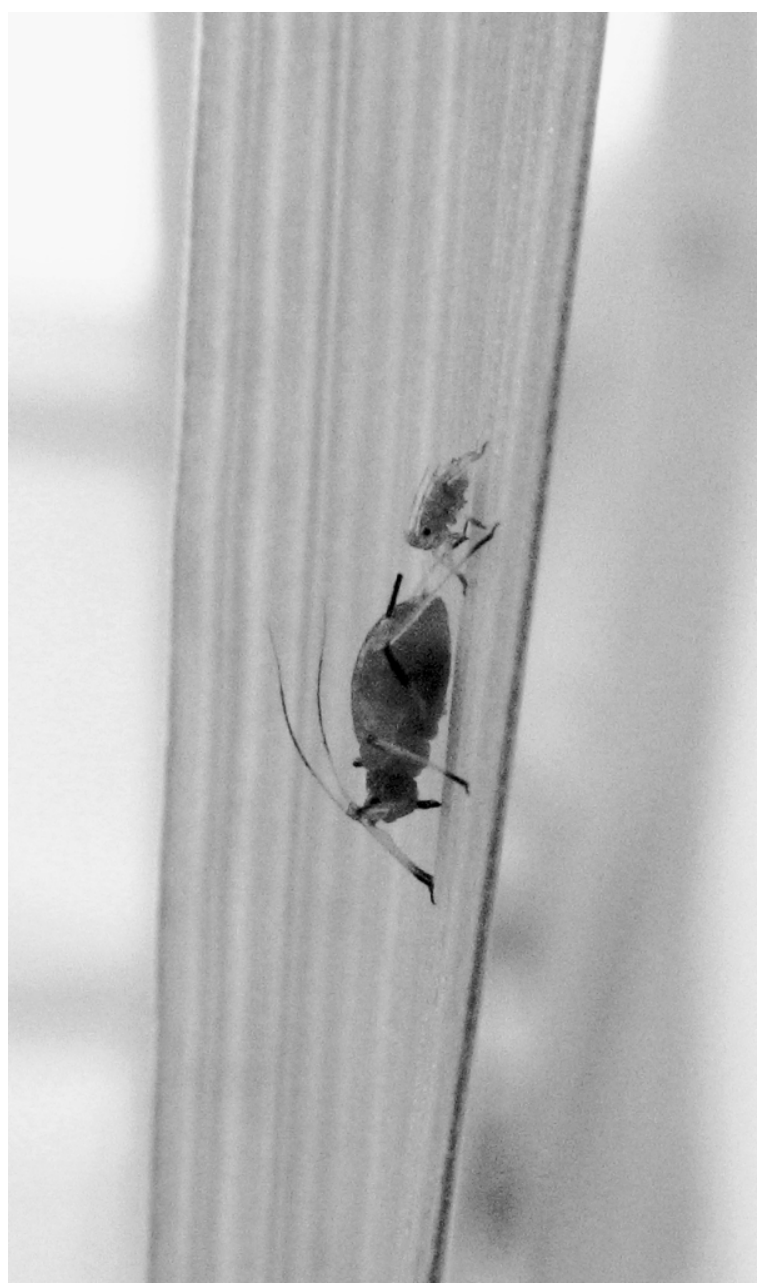

Plate 1. Sitobion avenae (Fab.), the English grain aphid, is a globally distributed vector of two barley yellow dwarf viruses (MAV and PAV) and is commonly found throughout the geographic range of this study. Photo credit: E. T. Borer and Mikal' Davis.

The only effect of the host community context that we detected was an increase in prevalence in one host species (B. hordeaceus) with increasing perennial grass cover (question 3). It is unlikely that our failure to detect a general, direct effect of host community composition on viral prevalence or diversity was due to a lack of variability in our data. Across our sampled sites, total standing biomass varied 40 -fold, host richness varied seven-fold, and the proportion of the community composed of hosts (grass cover/total cover) varied sixfold. However, experimental manipulation of host community composition may provide a more powerful approach for detecting the independent effects of the local host community composition, such as pathogen spillover (Power and Mitchell 2004, Malmstrom et al. 2005b).

The latitudinal gradient in coinfection was not driven by an increase in the total number of viral species present at our northern sites. Rather, infected hosts at northern sites carried a larger proportion of the available viral species pool, causing $\beta$ diversity to decline with latitude (question 4 in the Introduction). This decline in $\beta$ diversity is concordant with a switch from neutral communities with low transmission rates in the south to niche-assembled communities with high transmission at the northern sites (Dove and Cribb 2006). While higher rates of coinfection can, in general, arise not only from higher transmission rates, but also from lower loss rates of infection to recovery or mortality, this is less likely in our system because infected plants are not known to recover (Dempster and Holmes 1995). Furthermore, pathogen infections by the different $B / C Y D$ viruses were highly aggregated within hosts. B/CYD viruses efficiently transmitted by a shared vector were highly correlated across our sites, in concordance with an earlier study conducted using a single host collected across a much smaller spatial gradient (Seabloom et al. 2009). Theoretical work examining the drivers of coinfection suggests that the increase in coinfection with latitude may be driven by the local abundance of generalist vectors (Seabloom et al. 2009).

We selected a range of hosts for sampling that we expected a priori to differ strongly in their interactions with the $\mathrm{B} / \mathrm{CYD}$ viruses and the aphid vectors. While prevalence rates differed strongly among hosts, the among-host differences we observed were not those we expected based on aphid preferences for annual hosts and high fecundity of aphids feeding on annual hosts (Malmstrom et al. 2005b, Borer et al. 2009a; Appendix: Table 1). Rather than finding higher prevalence in our annual hosts, we found that the strongest differences in prevalence were between the two annual hosts (26\% infected for A. fatua and $15 \%$ infected for B. hordeaceus). We also found that the perennial host (23\% infected for E. glaucus) had a prevalence similar to the highest annual host (A.fatua) and 53\% higher than the annual host most preferred by aphids (B. hordeaceus; Appendix: Table 1). The higher-than-expected prevalence in the perennial host may reflect the more general patterns of gradual accumulation of viral infection over multiple years observed in other B/CYDV studies (Dempster and Holmes 1995, Power and Mitchell 2004, Seabloom et al. 2009).

The mismatch between prevalence and vector preference suggests that scaling population-level estimates of host-pathogen or host-vector interactions to larger spatial scales or complex natural communities may not be straightforward, and that the viral transmission properties of host species may not be consistent with their roles in vector regulation (Keesing et al. 2006). Future work to better characterize transmission competence and individual and population effects of infection on host species with a broad suite of characteristics will provide links to theory, allowing further insights into this field pattern, including the relative importance of host identity, host location, and host community context 
in determining host infection risk (e.g., Keesing et al. 2006). Here, we have shown that both host composition and the environment, including precipitation, latitude, and soil nitrate, can be important predictors of infection prevalence.

Our results also support the importance of abiotic environmental context in disease dynamics. Here, pathogen prevalence rates increased with soil nitrate levels in all host species. Nutrients have been implicated in elevating infection prevalence and severity for focal hosts in a variety of recent terrestrial, freshwater, and marine studies (Bruno et al. 2003, Johnson et al. 2007, Walters and Bingham 2007). More specifically, nutrient supplies have been shown to mediate vector populations of plant and animal pathogens by changing host or habitat quality (Pope et al. 2005, Borer et al. 2009a). The potential for a general role of nutrient supplies on vectored pathogens is of particular importance given the current rate at which humans are adding nutrients to Earth's ecosystems (Vitousek et al. 1997, Tilman et al. 2001, Townsend et al. 2003).

We note here that ascribing causation based on observational data requires caution, because of the covariance among predictive variables. For example, we found that prevalence was highest at sites with low precipitation. However, precipitation and soil phosphorous were inversely correlated in our data set $(r=-0.54)$, so these high prevalence sites also had higher soil phosphorous, an important limiting resource for some viruses (Clasen and Elser 2007). Ultimately, experimental manipulation of nutrients will be necessary to resolve the relative importance of abiotic factors that covary in these observational data.

As predicted by theory (Keesing et al. 2006), host community context also played a role in determining pathogen prevalence. However, this relationship was mediated by host-community interactions; prevalence in $B$. hordeaceus increased with the cover of perennial grasses, while prevalence in the other two focal hosts was unaffected of perennial grass cover. There is mounting evidence of the general importance of local host community composition and species richness in controlling pathogen prevalence. For example, increasing host richness is associated with reduced disease risk for several pathogens of both animals and plants (Mitchell et al. 2002, Ezenwa et al. 2006, Telfer et al. 2007), and compositional shifts that favor low competence rodent hosts can lower Lyme disease risk (LoGiudice et al. 2003). Our results emphasize that the effects of community context on disease risk may vary among focal host species. Thus, the characteristics of species in a community, and not simply total richness, may be critical to a more general understanding of host diversity effects on pathogen prevalence (Power and Mitchell 2004, Keesing et al. 2006, Mitchell and Power 2006).

While coinfection can have strong impacts on pathogen transmission and virulence and has been increasingly seen as an important risk factor in human diseases (Lal et al. 1994, Montefiori et al. 1996, Kamal et al. 2001a, b, Tirado and Yoon 2003), coinfection has received little attention in studies of natural systems in comparison to studies examining population-level prevalence rates (but see Lello et al. 2004, Jolles et al. 2008, Seabloom et al. 2009). Our results suggest that coinfection may be more predictable across geographic gradients than pathogen prevalence; in contrast to prevalence, all host species found at a site had similar levels of coinfection. Recent theory examining drivers of coinfection and prevalence suggests that interactions among virus species within hosts (e.g., synergistic mortality) should be weak to generate these results (Seabloom et al. 2009). In addition, coinfection in the current study was well-predicted by a single environmental factor, latitude, suggesting that site-level factors, rather than host-specific or within-host interactions, are the primary drivers of coinfection in this system.

We gain insights into the regulation of coinfection across this latitudinal gradient by applying well-developed theory from community ecology to disease systems (Guernier et al. 2004, Lello et al. 2004, Dove and Cribb 2006). As noted in studies of non-disease communities (Whittaker 1960, Harrison 1999), we might expect that local diversity ( $\alpha$ diversity) may arise as a balance between the total species pool at a site ( $\gamma$ diversity) and turnover of species among sites ( $\beta$ diversity; Whittaker 1960, Harrison et al. 1992, Dove and Cribb 2006). Applying this framework to this pathogen community, we demonstrate that the increase in coinfection with latitude results in a decline in pathogen species turnover among hosts at a site. This decline in species turnover with latitude indicates a shift from dispersal-assembled within-host pathogen communities at low latitudes to niche-assembled pathogen communities at high latitudes. Such a pattern is concordant with elevated transmission rates among hosts at high-latitude sites (Condit et al. 2002, Dove and Cribb 2006, Chase 2007). Recent theoretical work motivated by the B/CYD group of vectored viruses, suggests that increased within-host richness and transmission at our northern sites could arise from higher densities of generalist vectors leading to an overall increase in intrinsic transmission rates (Seabloom et al. 2009). Further detailed sampling or replicated experiments will be required to isolate the ultimate driver of this strong coinfection gradient.

The community ecology of disease is a relatively recent focus in ecological studies, with few theoretical frameworks or empirical tests (but see Lello et al. 2004, Collinge and Ray 2006b, Keesing et al. 2006, Jolles et al. 2008, Seabloom et al. 2009). Our understanding of observed patterns of generalist pathogen prevalence may become more complex as we incorporate host community context. However, the field of community ecology has demonstrated the existence of simple and general patterns governing diversity of free-living organisms, such as species-area relationships or the interdependen- 
cies of different components of diversity (i.e., $\alpha, \beta$, and $\gamma)$. Our current study suggests that such simple laws may also inform our understanding of pathogen diversity in natural communities.

\section{ACKNOWLEDGMENTS}

Support for this project was provided, in part, by NSF/NIH EID 05-25666 to E. T. Borer and E. W. Seabloom, NSF/NIH EID 05-25XYZ to A. G. Power, and NSF/NIH EID 05-25641 to C. E. Mitchell. We also thank the UC Natural Reserve System (Hastings, Mclaughlin, and Sedgwick), the UC Research and Extension Centers (Hopland and Sierra Foothill), and the U.S. Fish and Wildlife Service, Wildlife Refuge System (Finley and Baskett Slough). W. S. Harpole, A. Macdougal, B. Martin, and A. Brandt assisted in the collection of field data. K. Blaisdell, C. Kahlke, E. Pulley, K. Rienzo-Stack, S. Waring, and $\mathrm{M}$. Welsh assisted in conducting the viral assays.

\section{Literature Cited}

Agrios, G. N. 1978. Plant pathology. Second edition. Academic Press, Orlando, Florida, USA.

Al-Naimi, F. A., K. A. Garrett, and W. W. Bockus. 2005. Competition, facilitation, and niche differentiation in two foliar pathogens. Oecologia 143:449-457.

Anderson, R. M., and R. M. May. 1986. The invasion, persistence and spread of infectious diseases within animal and plant communities. Philosophical Transactions of the Royal Society B 314:533-570.

Ault, S. K. 1994. Environmental management: a reemerging vector control strategy. American Journal of Tropical Medicine and Hygiene 50:35-49.

Aylor, D. E. 1999. Biophysical scaling and the passive dispersal of fungus spores: relationship to integrated pest management strategies. Agricultural and Forest Meteorology 97:275-292.

Begon, M., R. G. Bowers, N. Kadianakis, and D. E. Hodgkinson. 1992. Disease and community structure: the importance of host self-regulation in a host-host-pathogen model. American Naturalist 139:1131-1150.

Bentwich, Z., A. Kalinkovich, Z. Weisman, G. Borkow, N. Beyers, and A. D. Beyers. 1999. Can eradication of helminthic infections change the face of AIDS and tuberculosis? Immunology Today 20:485-487.

Borer, E. T., V. T. Adams, G. A. Engler, A. L. Adams, C. B. Schumann, and E. W. Seabloom. 2009a. Aphid fecundity and grassland invasion: invader life history is the key. Ecological Applications 19:1187-1196.

Borer, E. T., P. R. Hosseini, E. W. Seabloom, and A. P. Dobson. 2007. Pathogen-induced reversal of native dominance in a grassland community. Proceedings of the National Academy of Sciences (USA) 104:5473-5478.

Borer, E. T., C. E. Mitchell, A. G. Power, and E. W. Seabloom. 2009 b. Consumers indirectly increase infection risk in grassland food webs. Proceedings of the National Academy of Sciences (USA) 106:503-506.

Bruno, J. F., L. E. Petes, C. D. Harvell, and A. Hettinger. 2003. Nutrient enrichment can increase the severity of coral diseases. Ecology Letters 6:1056-1061.

Caley, M. J., and D. Schluter. 1997. The relationship between local and regional diversity. Ecology 78:70-80.

Chase, J. M. 2007. Drought mediates the importance of stochastic community assembly. Proceedings of the National Academy of Sciences (USA) 104:17430-17434.

Clasen, J. L., and J. J. Elser. 2007. The effect of host Chlorella NC64A carbon:phosphorus ratio on the production of Paramecium bursaria Chlorella virus-1. Freshwater Biology $52: 112-122$

Coico, R., G. Sunshine, and E. Benjamini. 2003. Immunology: a short course. Fifth edition. Wiley-Liss, Hoboken, New Jersey, USA.
Collinge, S., and C. Ray. 2006a. Community epidemiology. Pages 1-5 in S. Collinge and C. Ray, editors. Disease ecology: community structure and pathogen dynamics. Oxford University Press, Oxford, UK.

Collinge, S., and C. Ray, editors. 2006b. Disease ecology: community structure and pathogen dynamics. Oxford University Press, Oxford, UK.

Condit, R. et al. 2002. Beta-diversity in tropical forest trees. Science 295:666-669.

Creamer, R., and B. W. Falk. 1990. Direct detection of transcapsidated barley yellow dwarf luteoviruses in doubly infected plants. Journal of General Virology 71:211-217.

Cumming, G. S., and J. F. Guegan. 2006. Food webs and disease: Is pathogen diversity limited by vector diversity? EcoHealth 3:163-170.

D'Arcy, C. 1995. Symptomology and host range of barley yellow dwarf. Pages 9-28 in C. J. D'Arcy and P. A. Burnett, editors. Barley yellow dwarf: 40 years of progress. American Phytopathological Society, St. Paul, Minnesota, USA.

Dempster, L. C., and S. J. I. Holmes. 1995. The incidence of strains of barley yellow dwarf virus in perennial ryegrass crops in south-west and central Scotland. Plant Pathology 44: $710-717$.

Dobson, A. 2004. Population dynamics of pathogens with multiple host species. American Naturalist 164:S64-S78.

Dobson, A. P. 2009. Climate variability, global change, immunity, and the dynamics of infectious diseases. Ecology 90:920-927.

Dove, A. D. M., and T. H. Cribb. 2006. Species accumulation curves and their applications in parasite ecology. Trends in Parasitology 22:568-574.

Ezenwa, V. O., M. S. Godsey, R. J. King, and S. C. Guptill. 2006. Avian diversity and West Nile virus: testing associations between biodiversity and infectious disease risk. Proceedings of the Royal Society B 273:109-117.

Fitt, B. D. L., H. A. McCartney, and P. J. Walklate. 1989. The role of rain in the dispersal of pathogen inoculum. Annual Review of Phytopathology 27:241-270.

Gildow, F. E., and W. F. Rochow. 1980. Transmission interference between two isolates of barley yellow dwarf virus in Macrosiphum avenae. Phytopathology 70:122-126.

Gray, S. M., A. G. Power, D. M. Smith, A. J. Seaman, and N. S. Altman. 1991. Aphid transmission of barley yellow dwarf virus: acquisition feeding periods and virus concentration requirements. Phytopathology 81:539-545.

Gregory, P. H. 1973. The microbiology of the atmosphere. Second edition. Leonard Hill, London, UK.

Guernier, V., M. E. Hochberg, and J. F. O. Guegan. 2004. Ecology drives the worldwide distribution of human diseases. PLoS Biology 2:740-746.

Halbert, S., and D. Voegtlin. 1995. Biology and taxonomy of vectors of barley yellow dwarf viruses. Pages 217-258 in C. J. D'Arcy and P. A. Burnett, editors. Barley yellow dwarf: 40 years of progress. American Phytopathological Society, St. Paul, Minnesota, USA.

Harrison, S. 1999. Local and regional diversity in a patchy landscape: native, alien, and endemic herbs on serpentine. Ecology 80:70-80.

Harrison, S., S. J. Ross, and J. H. Lawton. 1992. Beta diversity on geographic gradients in Britain. Journal of Animal Ecology 61:151-158.

Harvell, C. D. et al. 1999. Review: Emerging marine diseasesClimate links and anthropogenic factors. Science 285:15051510.

Harvell, C. D., C. E. Mitchell, J. R. Ward, S. Altizer, A. P. Dobson, R. S. Ostfeld, and M. D. Samuel. 2002. Climate warming and disease risks for terrestrial and marine biota. Science 296:2158-2162.

Heady, H. F. 1977. Valley grassland. Pages 491-514 in M. G. Barbour and J. Major, editors. Terrestrial vegetation of 
California. John Wiley and Sons, New York, New York, USA.

Hewings, A. D., and C. E. Eastman. 1995. Epidemiology of barley yellow dwarf in North America. Pages 75-106 in C. J. D'Arcy and P. A. Burnett, editors. Barley yellow dwarf: 40 years of progress. American Phytopathological Society, St. Paul, Minnesota, USA.

Holmes, J. C., and P. W. Price. 1986. Communities of parasites. Pages 187-213 in D. J. Anderson and J. Kikkawa, editors. Community ecology: pattern and process. Blackwell Scientific Publications, Oxford, UK.

Holt, R. D., A. P. Dobson, M. Begon, R. G. Bowers, and E. M. Schauber. 2003. Parasite establishment in host communities. Ecology Letters 6:837-842.

Hood, M. E. 2003. Dynamics of multiple infection and withinhost competition by the anther-smut pathogen. American Naturalist 162:122-133.

Irwin, M. E., and J. M. Thresh. 1988. Long-range aerial dispersal of cereal aphids as virus vectors in North America. Philosophical Transactions of the Royal Society B 321:421446.

Irwin, M. E., and J. M. Thresh. 1990. Epidemiology of barley yellow dwarf: a study in ecological complexity. Annual Review of Phytopathology 28:393-424.

Johnson, P. T. J., J. M. Chase, K. L. Dosch, R. B. Hartson, J. A. Gross, D. J. Larson, D. R. Sutherland, and S. R. Carpenter. 2007. Aquatic eutrophication promotes pathogenic infection in amphibians. Proceedings of the National Academy of Sciences (USA) 104:15781-15786.

Jolles, A. E., V. O. Ezenwa, R. S. Etienne, W. C. Turner, and H. Olff. 2008. Interactions between macroparasites and microparasites drive infection patterns in free-ranging African buffalo. Ecology 89:2239-2250.

Kamal, S. M., L. Bianchi, A. Al Tawil, M. Koziel, K. E. Khalifa, T. Peter, and J. W. Rasenack. 2001a. Specific cellular immune response and cytokine patterns in patients coinfected with hepatitis $\mathrm{C}$ virus and Schistosoma mansoni. Journal of Infectious Diseases 184:972-982.

Kamal, S. M., J. W. Rasenack, L. Bianchi, A. Al Tawil, K. E. S. Khalifa, T. Peter, H. Mansour, W. Ezzat, and M. Koziel. 2001b. Acute hepatitis C without and with schistosomiasis: correlation with hepatitis C-specific CD4(+) T-cell and cytokine response. Gastroenterology 121:646-656.

Keesing, F., R. D. Holt, and R. S. Ostfeld. 2006. Effects of species diversity on disease risk. Ecology Letters 9:485-498.

Koskella, B., T. Giraud, and M. E. Hood. 2006. Pathogen relatedness affects the prevalence of within-host competition. American Naturalist 168:121-126.

Lal, R. B., D. Rudolph, M. P. Alpers, A. J. Sulzer, Y. P. Shi, and A. A. Lal. 1994. Immunologic cross-reactivity between structural proteins of human T-cell lymphotropic virus type I and the blood stage of Plasmodium falciparum. Clinical and Diagnostic Laboratory Immunology 1:5-10.

Leclercq-Le Quillec, F., M. Plantegenest, G. Riault, and C. A. Dedryver. 2000. Analyzing and modeling temporal disease progress of barley yellow dwarf virus serotypes in barley fields. Phytopathology 90:860-866.

Lello, J., B. Boag, A. Fenton, I. R. Stevenson, and P. J. Hudson. 2004. Competition and mutualism among the gut helminths of a mammalian host. Nature 428:840-844.

Lindsay, S. W., and M. H. Birley. 1996. Climate change and malaria transmission. Annals of Tropical Medicine and Parasitology 90:573-588.

LoGiudice, K., R. S. Ostfeld, K. A. Schmidt, and F. Keesing. 2003. The ecology of infectious disease: effects of host diversity and community composition on Lyme disease risk. Proceedings of the National Academy of Sciences (USA) 100: 567-571.

Macdonald, G. 1957. The epidemiology and control of malaria. Oxford University Press, London, UK.
Madden, L. V., X. S. Yang, and L. L. Wilson. 1996. Effects of rain intensity on splash dispersal of Colletotrichum acutatum. Phytopathology 86:864-874.

Malmstrom, C. M., C. C. Hughes, L. A. Newton, and C. J. Stoner. 2005a. Virus infection in remnant native bunch grasses from invaded California grasslands. New Phytologist 168:217-230.

Malmstrom, C. M., A. J. McCullough, H. A. Johnson, L. A. Newton, and E. T. Borer. 2005b. Invasive annual grasses indirectly increase virus incidence in California native perennial bunchgrasses. Oecologia 145:153-164.

Manly, B. F. J. 1986. Multivariate statistical methods: a primer. Chapman and Hall, London, UK.

Mantel, N. 1967. The detection of disease clustering and a generalized regression approach. Cancer Research 27:209220.

McCullagh, P., and J. A. Nelder. 1989. Generalized linear models. Second edition. Chapman and Hall, New York, New York, USA.

Miller, W. A., and L. Rasochova. 1997. Barley yellow dwarf viruses. Annual Review of Phytopathology 35:167-190.

Minakawa, N., E. Omukunda, G. F. Zhou, A. Githeko, and G. Y. Yan. 2006. Malaria vector productivity in relation to the highland environment in Kenya. American Journal of Tropical Medicine and Hygiene 75:448-453.

Mitchell, C. E., and A. G. Power. 2006. Disease dynamics in plant communities. Page 58-72 in S. Collinge and C. Ray, editors. Disease ecology: community structure and pathogen dynamics. Oxford University Press, Oxford, UK.

Mitchell, C. E., D. Tilman, and J. V. Groth. 2002. Effects of grassland plant species diversity, abundance, and composition on foliar fungal disease. Ecology 83:1713-1726.

Montefiori, D. C., G. Pantaleo, L. M. Fink, J. T. Zhou, J. Y. Zhou, M. Bilska, G. D. Miralles, and A. S. Fauci. 1996. Neutralizing and infection-enhancing antibody responses to human immunodeficiency virus type 1 in long-term nonprogressors. Journal of Infectious Diseases 173:60-67.

Norman, R. M., M. Begon, and R. G. Bowers. 1994. The population dynamics of microparasites and vertebrate hosts: the importance of immunity and recovery. Theoretical Population Biology 46:96-119.

Packer, C., R. D. Holt, P. J. Hudson, K. D. Lafferty, and A. P. Dobson. 2003. Keeping the herds healthy and alert: implications of predator control for infectious disease. Ecology Letters 6:797-802.

Pedersen, A. B., and A. Fenton. 2007. Emphasizing the ecology in parasite community ecology. Trends in Ecology and Evolution 22:133-139.

Pope, K., P. Masuoka, E. Rejmankova, J. Grieco, S. Johnson, and D. Roberts. 2005. Mosquito habitats, land use, and malaria risk in Belize from satellite imagery. Ecological Applications 15:1223-1232.

Pounds, J. A., et al. 2006. Widespread amphibian extinctions from epidemic disease driven by global warming. Nature 439: 161-167.

Power, A. G. 1996. Competition between viruses in a complex plant-pathogen system. Ecology 77:1004-1010.

Power, A. G., and S. M. Gray. 1995. Aphid transmission of barley yellow dwarf viruses: interactions between viruses, vectors, and host plants. Pages 259-289 in C. J. D'Arcy and P. A. Burnett, editors. Barley yellow dwarf: 40 years of progress. American Phytopathological Society, St. Paul, Minnesota, USA.

Power, A. G., and C. E. Mitchell. 2004. Pathogen spillover in disease epidemics. American Naturalist 164:S79-S89.

Power, A. G., A. J. Seaman, and S. M. Gray. 1991. Aphid transmission of barley yellow dwarf virus: inoculation feeding periods and epidemiological implications. Phytopathology 81:545-548. 
R Development Core Team. 2007. R: a language and environment for statistical computing. R Foundation for Statistical Computing, Vienna, Austria.

Reiter, P. 2001. Climate change and mosquito-borne disease. Environmental Health Perspectives 109:141-161.

Rochow, W. F. 1970a. Barley yellow dwarf virus. No. 32 in Descriptions of plant viruses. Commonwealth Mycological Institute and Association of Applied Biologists, Kew, Surrey, England.

Rochow, W. F. 1970b. Barley yellow dwarf virus: phenotypic mixing and vector specificity. Science 167:875-878.

Rochow, W. F. 1986. Barley yellow dwarf virus. Methods for Enzyme Analysis 11:420-430.

Seabloom, E. W., W. S. Harpole, O. J. Reichman, and D. Tilman. 2003. Invasion, competitive dominance, and resource use by exotic and native California grassland species. Proceedings of the National Academy of Sciences (USA) 100:13384-13389.

Seabloom, E. W., P. R. Hosseini, A. G. Power, and E. T. Borer. 2009. Diversity and composition of viral communities: coinfection of barley and cereal yellow dwarf viruses in California grasslands. American Naturalist 173:E79-E98.

Service, M. W. 1976. Mosquito ecology: field sampling methods. Applied Science Publishers, London, UK.

Shrestha, S., S. A. Strathdee, N. Galai, T. Oleksyk, M. D. Fallin, S. Mehta, D. Schaid, D. Vlahov, S. J. O'Brien, and M. W. Smith. 2006. Behavioral risk exposure and host genetics of susceptibility to HIV-1 infection. Journal of Infectious Diseases 193:16-26.

Snall, T., R. B. O'Hara, C. Ray, and S. K. Collinge. 2008. Climate-driven spatial dynamics of plague among prairie dog colonies. American Naturalist 171:238-248.

Sokal, R. R., and F. J. Rohlf. 1995. Biometry: the principles and practice of statistics in biological research. Third edition. W. H. Freeman, New York, New York, USA.

Telfer, S., M. Begon, M. Bennett, K. J. Bown, S. Burthe, X. Lambin, G. Telford, and R. Birtles. 2007. Contrasting dynamics of Bartonella spp. in cyclic field vole populations: the impact of vector and host dynamics. Parasitology 134: 413-425.

Tilman, D., J. Fargione, B. Wolff, C. D'Antonio, A. Dobson, R. Howarth, D. Schindler, W. H. Schlesinger, D. Simberloff, and D. Swackhamer. 2001. Forecasting agriculturally driven global environmental change. Science 292:281-284.

Tirado, S. M. C., and K. J. Yoon. 2003. Antibody-dependent enhancement of virus infection and disease. Viral Immunology 16:69-86.

Townsend, A. R. et al. 2003. Human health effects of a changing global nitrogen cycle. Frontiers in Ecology and the Environment 1:240-246.

Venables, W. N., and B. D. Ripley. 2003. Modern applied statistics with S. Springer, New York, New York, USA.

Vitousek, P. M., H. A. Mooney, J. Lubchenko, and J. M. Melillo. 1997. Human domination of earth's ecosystems. Science 277:494-499.

Walters, D. R., and I. J. Bingham. 2007. Influence of nutrition on disease development caused by fungal pathogens: implications for plant disease control. Annals of Applied Biology 151:307-324.

Wen, F., R. M. Lister, and F. A. Fattouh. 1991. Crossprotection among strains of barley yellow dwarf virus. Journal of General Virology 72:791-799.

Whittaker, R. H. 1960. Vegetation of the Siskiyou Mountains, Oregon and California. Ecological Monographs 30:279-338.

Whittaker, R. J., K. J. Willis, and R. Field. 2001. Scale and species richness: towards a general, hierarchical theory of species diversity. Journal of Biogeography 28:453-470.

Woolhouse, M. E. J., L. H. Taylor, and D. T. Haydon. 2001. Population biology of multihost pathogens. Science 292: 1109-1112.

Yazdanbakhsh, M., P. G. Kremsner, and R. van Ree. 2002. Immunology: allergy, parasites, and the hygiene hypothesis. Science 296:490-494.

Zhou, G., N. Minakawa, A. K. Githeko, and G. Y. Yan. 2004. Association between climate variability and malaria epidemics in the East African highlands. Proceedings of the National Academy of Sciences (USA) 101:2375-2380.

\section{APPENDIX}

Tables showing provenance, lifespan, and pathogen interactions of the monitored hosts; site locations, precipitation, soil nitrate, overall viral prevalence, and viruses per host averaged across three host species of four barley and cereal yellow dwarf viruses in 26 Pacific Coast grasslands; among-host comparisons in prevalence and viral species diversity in infected hosts; environmental drivers of prevalence and viral species diversity averaged across three host species; and effects of soil nitrogen on prevalence and viral species diversity averaged across three host species (Ecological Archives E091-052-A1). 


\section{Ecological Archives E091-052-A1}

\section{Eric W. Seabloom, Elizabeth T. Borer, Charles E. Mitchell, and Alison G. Power. 2010. Viral diversity and prevalence gradients in North American Pacific Coast grasslands. Ecology 91:721-732.}

Appendix A. Tables showing provenance, lifespan, and pathogen interactions of the monitored hosts; site locations, precipitation, soil nitrate, overall viral prevalence, and viruses per host averaged across three host species of four barley and cereal yellow dwarf viruses in 26 Pacific Coast grasslands; among-host comparisons in prevalence and viral species diversity in infected hosts; environmental drivers of prevalence and viral species diversity averaged across three host species; and effects of soil nitrogen on prevalence and viral species diversity averaged across three host species.

TABLE A1. Provenance, lifespan, and pathogen interactions of the monitored hosts. All hosts are from the subfamily Pooideae.

$\begin{array}{ccc}\text { Avena } & \text { Bromus } & \text { Elymus } \\ \text { Fatua } & \text { hordeaceus } & \text { glaucus }\end{array}$

Life span

Provenance

Vector fecundity (aphids day $\left.{ }^{-1}\right)^{a}$

Vector preference (aphids $\mathrm{g}^{-1}$ of host) ${ }^{\mathrm{b}}$

Pathogen-induced reduction in fecundity c

Pathogen-induced reduction in among-year survival d

Tribe within the Poaceae

$\begin{array}{rrr}\text { Annual } & \text { Annual } & \text { Perennial } \\ \text { Exotic } & \text { Exotic } & \text { Native } \\ 1.08 & 1.03 & 0.52 \\ 14.41 & 17.86 & 2.62 \\ 0.41 & 0.39 & 0.23 \\ \text { NA } & \text { NA } & 0.12 \\ \text { Poeae } & \text { Bromeae } & \text { Hordeinae }\end{array}$

a Aphid production based on experimental out-plants (Borer et al. 2009).

b Aphid density in foraging preference trials adjusted for host size (grams of dry tissue) (Borer et al. 2009).

c Reduction in fecundity in inoculated plants (C. E. Mitchell, unpublished data).

d Increase in among-year mortality in inoculated plants (Malmstrom et al. 2005, Borer et al. 2007)

TABLE A2. Site locations, precipitation, soil nitrate, overall viral prevalence, and viruses per host average across three host species of four barley and cereal yellow dwarf viruses in 26 Pacific Coast grasslands.

Prevalence and species diversity are averaged across three host grasses: Avena fatua, Bromus hordeaceus, and Elymus glaucus.

\begin{tabular}{|c|c|c|c|c|c|c|c|c|c|}
\hline $\begin{array}{l}\text { State/ } \\
\text { Province }\end{array}$ & County & Reserve & Site & $\begin{array}{c}\text { Overall } \\
\text { infection } \\
\text { proportion }\end{array}$ & $\begin{array}{c}\text { Viral } \\
\text { species } \\
\text { per host }\end{array}$ & Latitude & Longitude & $\begin{array}{c}2006 \\
\text { precipitation } \\
(\mathrm{mm})\end{array}$ & $\begin{array}{c}\text { Soil } \\
\text { nitrate } \\
\text { (ppm) }\end{array}$ \\
\hline British Columbia & Vancouver Island & NA & Cowichan Annual & 0.300 & 2.167 & 48.810 & -122.369 & 1285 & NA \\
\hline British Columbia & Vancouver Island & NA & Cowichan Perennial & 0.050 & 3.000 & 48.810 & -122.369 & 1285 & NA \\
\hline Oregon & Polk & Baskett Slough & Smithfield Rd. & 0.200 & 1.500 & 44.962 & -122.738 & 1448 & 10 \\
\hline Oregon & Polk & Baskett Slough & Baskett Butte & 0.105 & 2.500 & 44.962 & -122.738 & 1448 & 10 \\
\hline
\end{tabular}




\begin{tabular}{|c|c|c|c|c|c|c|c|c|c|}
\hline Oregon & Benton & W. L. Finley & Bruce Rd. & 0.350 & 2.286 & 44.421 & -122.676 & 1094 & 10 \\
\hline Oregon & Benton & W. L. Finley & Quarry & 0.700 & 2.071 & 44.421 & -122.676 & 1094 & 10 \\
\hline Oregon & Benton & W. L. Finley & Pigeon Butte & 0.250 & 2.200 & 44.421 & -122.676 & 1094 & 10 \\
\hline Oregon & Benton & Fort Hoskins & Collins & 0.475 & 1.786 & 44.408 & -122.722 & 1094 & 10 \\
\hline Oregon & Linn & Horserock Ridge & IAE & 0.100 & 1.500 & 44.107 & -122.926 & 1504 & NA \\
\hline California & Yuba & Sierra Foothill & Koch Rd6 & 0.000 & NA & 39.294 & -121.288 & 1001 & 2 \\
\hline California & Yuba & Sierra Foothill & Koch K6 & 0.100 & 1.000 & 39.285 & -121.289 & 1001 & 5 \\
\hline California & Yuba & Sierra Foothill & Camp & 0.143 & 1.500 & 39.256 & -121.280 & 1001 & 6 \\
\hline California & Mendocino & Hopland & Riley & 0.050 & 1.500 & 39.015 & -123.060 & 1029 & 2 \\
\hline California & Mendocino & Hopland & Foster & 0.000 & NA & 39.003 & -123.090 & 1029 & 1 \\
\hline California & Mendocino & Hopland & Lake & 0.050 & 1.000 & 38.995 & -123.070 & 1382 & 2 \\
\hline California & Yolo & McLaughlin & Reservoir & 0.050 & 1.333 & 38.857 & -122.362 & 1067 & 2 \\
\hline California & Yolo & McLaughlin & Middle & 0.033 & 1.000 & 38.853 & -122.366 & 1067 & 2 \\
\hline California & Napa & McLaughlin & Mine Pit & 0.050 & 2.000 & 38.842 & -122.356 & 1067 & 4 \\
\hline California & Monterey & Hastings & Native & 0.150 & 1.800 & 36.387 & -121.554 & 627 & 3 \\
\hline California & Monterey & Hastings & Schoolhouse & 0.150 & 1.611 & 36.385 & -121.548 & 627 & 2 \\
\hline California & Monterey & Hastings & Martin Road & 0.150 & 2.000 & 36.379 & -121.549 & 627 & 3 \\
\hline California & Santa Barbara & Sedgwick & Figueroa & 0.509 & 1.444 & 34.718 & -120.050 & 434 & 6 \\
\hline California & Santa Barbara & Sedgwick & Lisque & 0.500 & 1.178 & 34.718 & -120.050 & 434 & 8 \\
\hline California & Santa Barbara & Sedgwick & Middle & 0.217 & 1.254 & 34.718 & -120.050 & 434 & 8 \\
\hline California & Orange & Irvine Ranch & Irvine Annual & 0.451 & 1.429 & 33.751 & -117.683 & 224 & 10 \\
\hline California & Orange & Irvine Ranch & Irvine Perennial & 0.250 & 1.286 & 33.751 & -117.683 & 224 & 10 \\
\hline
\end{tabular}

TABLE A3. Among host comparisons in prevalence and viral species diversity in infected hosts. The final model includes only significant terms based on backwards selection ${ }^{\mathrm{a}}$.

Response

Prevalence $(\mathrm{df}=49)$

Source

Intercept

Avena vs. Bromus hosts

Perennial vs. annual hosts

Latitude (degrees)

Precipitation in $2006(\mathrm{~mm})$

Avena $\times$ Peren. Grass Cover
$-12.669$

0.924

0.245

0.411

$-0.005$

$-0.051$
Std. Error $t$ value
$-4.506$

0.000

0.306

0.306

3.020

0.004

$\begin{array}{lll}0.159 & 1.544 & 0.130\end{array}$

0.093

4.408

0.000

$\begin{array}{lll}0.001 & -5.021 & 0.000\end{array}$

$0.032 \quad-1.591$

0.119 
Intercept

Latitude (degrees)
$-0.029$

$-0.977$

0.037
Bromus $\times$ Peren. Grass Cover

0.044

Elymus $\times$ Peren. Grass Cover

$\alpha$ diversity (strains per host; $\mathrm{df}=40$ )
0.019

2.270

0.028

0.015

$-1.943$

0.059

$a$ diversity (strains per host; $d f=40)$
0.433

$-2.257$

0.030

$0.011 \quad 3.396$

aTotal aboveground biomass, host richness, cover of non-hosts, and cover of perennial grasses were included in the full model, but were not significant in any final models.

Nonsignificant contrasts were left in the final model if one of the contrasts was significant.

TABLE A4. Environmental drivers of prevalence and viral species diversity ( $\alpha, \beta$, and $\gamma$ ) averaged across three host species. The final model includes only significant terms based on backwards selectiona ${ }^{\mathrm{a}}$

\begin{tabular}{|c|c|c|c|c|c|}
\hline Response & Source & Estimate & Std. Error & $t$ value & $P$ \\
\hline \multirow[t]{3}{*}{ Prevalence $(\mathrm{df}=25)$} & Intercept & -10.375 & 2.532 & -4.097 & 0.000 \\
\hline & Latitude (degrees) & 0.337 & 0.085 & 3.989 & 0.001 \\
\hline & Precipitation in 2006 (mm) & -0.005 & 0.001 & -4.562 & 0.000 \\
\hline \multirow[t]{3}{*}{$\alpha$ diversity (viruses per host; $\mathrm{df}=23$ ) } & Intercept & -2.049 & 0.499 & -4.108 & 0.001 \\
\hline & Latitude (degrees) & 0.076 & 0.016 & 4.732 & 0.000 \\
\hline & Precipitation in 2006 (mm) & -0.001 & 0.000 & -2.511 & 0.020 \\
\hline \multirow[t]{2}{*}{$\beta$ diversity $(a / g ; \mathrm{df}=23)$} & Intercept & 2.454 & 0.497 & 4.942 & 0.000 \\
\hline & Latitude (degrees) & -0.046 & 0.013 & -3.661 & 0.001 \\
\hline$\gamma$ diversity (viruses per site; $\mathrm{df}=23$ ) & Intercept & 1.099 & 0.060 & 18.250 & 0.000 \\
\hline
\end{tabular}

aTotal aboveground biomass, host richness, cover of non-hosts, and cover of perennial grasses were included in the full model, but were not significant in any final models. Nonsignificant contrasts were left in the final model if one of the contrasts was significant.

TABLE A5. Effects of soil nitrogen (nitrate) on prevalence and viral species diversity ( $\alpha, \beta$, and $\gamma$ ) averaged across three host species.

Nitrate data were missing at three sites, and so were not included in the full regression models in Tables A3 and A4.

Response $\quad$ Source $\quad$ Estimate Std. Error $t$ value $P$




$\begin{array}{llrrrr}\text { Prevalence }(\mathrm{df}=22) & \text { Intercept } & -2.761 & 0.438 & -6.306 & 0.000 \\ & \text { Soil nitrate }(\mathrm{ppm}) & 0.233 & 0.059 & 3.932 & 0.001 \\ \alpha \text { diversity (viruses per host; } \mathrm{df}=20) & \text { Intercept } & 0.270 & 0.127 & 2.131 & 0.046 \\ & \text { Soil nitrate }(\mathrm{ppm}) & 0.031 & 0.017 & 1.830 & 0.083 \\ \beta \text { diversity }(\alpha / \gamma ; \mathrm{df}=20) & \text { Intercept } & 0.669 & 0.157 & 4.263 & 0.000 \\ & \text { Soil nitrate }(\mathrm{ppm}) & 0.001 & 0.022 & 0.030 & 0.976 \\ \gamma \text { diversity (viruses per site; } \mathrm{df}=20) & \text { Intercept } & 0.983 & 0.148 & 6.650 & 0.000 \\ & \text { Soil nitrate }(\mathrm{ppm}) & 0.02044 & 0.02007 & 1.019 & 0.321\end{array}$

\section{LITERATURE CITED}

Borer, E. T., V. Adams, G. A. Engler, A. Adams, C. Schumann, and E. W. Seabloom. 2009. Responses by aphid-vectors of a generalist viral pathogen to host life history, provenance, and nutrition. Ecological Applications 19:1187-1196.

Borer, E. T., P. R. Hosseini, E. W. Seabloom, and A. P. Dobson. 2007. Pathogen-induced reversal of native dominance in a grassland community. Proceedings of the National Academy of Sciences of the United States of America 104:5473-5478.

Malmstrom, C. M., C. C. Hughes, L. A. Newton, and C. J. Stoner. 2005. Virus infection in remnant native bunchgrasses from invaded California grasslands. New Phytologist 168:217-230. 